\title{
VIEWPOINT
}

\section{Negative emission farming}

Rattan Lal

$\mathrm{n}$ comparison with levels in 2000, global carbon dioxide $\left(\mathrm{CO}_{2}\right)$ has increased by $43.5 \mathrm{ppm}$ to $414.4 \mathrm{ppm}$ during 2020, an increase of $12 \%$. Indeed, concentration of atmospheric $\mathrm{CO}_{2}$ now is higher than at any time during the past 3.6 million years (Stein 2021). Similarly, the global average concentration of methane $\left(\mathrm{CH}_{4}\right)$ for December of 2020 was $1,892.3$ $\mathrm{ppb}$, representing an increase of about 119 ppb (6\%) since 2000 (Stein 2021). Despite the shutdown caused by the COVID-19 pandemic, the increase in atmospheric concentration of $\mathrm{CO}_{2}$ during 2020 may be among the largest for the entire period since the records started. There has also been notable increase in atmospheric concentration of nitrous oxide $\left(\mathrm{N}_{2} \mathrm{O}\right)$, primarily due to the use of nitrogenous fertilizers (WMO 2020). Thus, there is a strong need to identify sources and sinks of these gases, especially those of $\mathrm{CH}_{4}$ and $\mathrm{N}_{2} \mathrm{O}$, which are 28 and 285 times more potent, respectively, in trapping heat than is $\mathrm{CO}_{2}$ (IPCC 2007).

While known sources include fossil fuel combustion, land use conversion, biomass burning, rice paddies, cattle production, etc., the role of soil processes has not been given the emphasis that is deserves. Whereas science-based and sustainable use of soils of agro-ecosystems and other managed land uses can be a sink for $\mathrm{CO}_{2}$ and $\mathrm{CH}_{4}$, soils prone to degradation by diverse processes (e.g., decline in soil structure, compaction, anaerobiosis, erosion/deposition) can be sources of $\mathrm{CH}_{4}$ through methanogenesis and of $\mathrm{N}_{2} \mathrm{O}$ through nitrification and denitrification. The impact of soil degradation, difficult and challenging to quantify as it may be, cannot be ignored (Stein 2021). There is growing interest in making agriculture a solution to the global problem of climate change because agriculture contributes about one-third of the $\mathrm{CO}_{2}$ equivalent of all anthropogenic emissions (IPCC 2018), both directly and indirectly. Simultaneously, meeting the demand for adequate amounts of nutri- tious and safe food for each of the 7.8 billion people is important to achieving the \#2 goal (zero hunger) of the 17 Sustainable Development Goals of the United Nations' Agenda 2030. Advancing food and nutritional security is also the theme of the United Nations Food System Summit scheduled for the fall 2021.

The urgency of these global issues (i.e., climate change, food and nutritional insecurity, increasing extent and severity of soil and environmental degradation) has created proliferation of terms aimed at transforming agriculture. Examples of commonly used terms include net zeroemission agriculture (Pradhan et al. 2018; Nisbet et al. 2020; Wang et al. 2021), net zero $\mathrm{CO}_{2}$ (Tanneberger et al. 2021), zerocarbon (C) era (Ahn and Cowern 2011), zero emissions farming systems or production (Ulgiati et al. 2008; Thanh Hai et al. 2020), net-zero deep decarbonization (Bataille et al. 2020), low-C farming (Sà et al. 2017; Dou 2018), and C-neutral farming (Torres et al. 2015). These terms are increasingly being used as policy relevant indicators (Arnell et al. 2021) and as a rhetoric to stimulate a global endeavor to limit the increase of global average temperature to $1.5^{\circ} \mathrm{C}\left(2.7^{\circ} \mathrm{F}\right)$ or at the most to $2^{\circ} \mathrm{C}\left(3.6^{\circ} \mathrm{F}\right)$ above the preindustrial level. Whereas the overall strategy is that the global net $\mathrm{CO}_{2}$ emissions are reduced to zero by 2050 (UNFCCC 2015), the range of terminology being used is confounding the problem and aggravating the confusion among farmers, land managers, researchers, and the policy makers. Even the strategy of adopting "climate neutral" options is not good enough because of the urgent need to adopt technologies which create negative emission and substantially reduce concentration of greenhouse gases (GHGs) in the atmosphere. It is precisely in this context that proliferation of these ad hoc terms can be counterproductive. In this context, use of the term "climate smart agriculture" (Ross 2016; Abegunde et al. 2019; Brohm and Klein 2020), while apparently appropriate, is neither specific enough nor directly focuses on creating drawdown of GHGs from the atmosphere. Indeed, the underlying concept must be clearly defined and understood by all intended users (Źukowska et al. 2016). Therefore, the objective of this article is to deliberate the basic issues related to the role of agriculture in achieving negative emission farming (NEF) by identifying technological options that increase agronomic productivity but also minimize emissions of GHGs (especially $\mathrm{CH}_{4}$ and $\mathrm{N}_{2} \mathrm{O}$ ) through adoption of recommended management practices (RMPs).

\section{NEGATIVE EMISSION FARMING}

The Paris Agreement of 2015 calls for a global effort to preferably limit the global warming to $1.5^{\circ} \mathrm{C}\left(2.7^{\circ} \mathrm{F}\right)$, but no more than $2^{\circ} \mathrm{C}\left(3.6^{\circ} \mathrm{F}\right)$ by 2050 (Tanneberger et al. 2021). In this regard, agriculture must create strong net negative emissions, not just zero emissions. Achieving net zero emissions is an attractive slogan for industry (e.g., Danone, Microsoft, Sony, Panasonic) and doable by reducing emissions and substituting fossil fuel with solar or geothermal energy, etc., but it is not applicable to agriculture and, even if accomplished, cannot feed the growing and increasingly affluent world population. The use of the term "net zero emission" is similar to the use of the term "leakage" in geological sequestration of $\mathrm{CO}_{2}$ by injecting emissions from industrial installations (e.g., coal-fired power plant, ethanol production from corn grains) into saline aquifers and stable geological strata. Carbon dioxide thus injected is prone to leakage via cracks and crevices in rocks. However, there is no similarity of the process of geological injection to that of the natural process of $\mathrm{C}$ sequestration in the surface $1 \mathrm{~m}(3.28 \mathrm{ft})$ of the surface soil, and the use of the term "leakage" to C seques-

Rattan Lal is a distinguished professor of soil science and is the director of the Carbon Management and Sequestration Center, The Ohio State University, Columbus, Ohio.

Received April 19, 2021. 
tration in agricultural and other terrestrial ecosystems is confusing and irrelevant.

An urgent need of the present era is to promote adoption of RMPs to enhance and sustain quantity and quality of food by improving the net ecosystem productivity and the net biome productivity (Jansson et al. 2010) while reducing losses due to erosion, fire, and other degradative processes (e.g., methanogenesis and denitrification caused by anaerobic soil conditions). The latter requires a lot more productivity (through photosynthesis) per unit area while restoring soil quality and functionality than just to offset emissions from farm operations (i.e., tillage, chemical use, irrigation, harvesting). In addition to the choice of appropriate species and improved varieties adapted to site-specific conditions, restoration of soil health by sequestration of soil organic C (SOC) and soil inorganic C (SIC) (Lal 2018; Lal et al. 2021) is critical to achieving the high and sustained production that NEF is intended to achieve.

Nonetheless, prudent management of sources and sinks of GHGs is critical to achieving the NEF (table 1). For example, widespread adoption of system-based conservation agriculture is globally recognized as an efficient soil management option to reduce risks of soil erosion, conserve water in the root zone, reduce the $\mathrm{C}$ footprint production systems (Xiao et al. 2020; Lal 2015; Chen et al.2021), and sustain productivity and nutritional quality of the food. Ecological agriculture, based on the concept of eco-intensification, can also enhance productivity (Ullah et al. 2020). The goal is to develop synergism between the mitigation of and adaptation to climate change (Smith and Olesen 2010). Restoration of peatland (e.g., stopping cultivation, reflooding, and reforestation) is also an important consideration (Tanneberger et al.2021) to achieving NEF. Therefore, sources of GHG emissions must be reduced and sinks for atmospheric $\mathrm{CO}_{2}$ increased, especially that of SOC, which leads to high food production (figure 1). Major sources of emissions include farm operations involving use of diesel/ energy, inputs of agrochemicals (chemical fertilizers, pesticides, herbicides), excessive tillage and the attendant increase in risks of accelerated soil erosion and decomposition of soil organic matter, and emission of $\mathrm{CH}_{4}$

\section{Table 1}

Managing sources and sinks of greenhouse gases for achieving negative emission farming.

\begin{tabular}{|c|c|}
\hline Management & References \\
\hline \multicolumn{2}{|l|}{ Sources } \\
\hline - Cultivation of peatlands & Tanneberger et al. 2021 \\
\hline - Diesel/power consumption & Chandio et al. 2020 \\
\hline $\begin{array}{l}\text { - Intensive farming and indiscriminately/ad hoc } \\
\text { use of chemicals and energy }\end{array}$ & Dorneanu 2017 \\
\hline \multicolumn{2}{|l|}{ Sinks } \\
\hline - Photosynthesis and high crop yield & Frankelius 2020 \\
\hline $\begin{array}{l}\text { - Conservation agriculture, residue retention } \\
\text { complex rotations }\end{array}$ & Chen et al. 2021 \\
\hline - Restoration of peat lands & Xiao et al. 2020 \\
\hline - Integration of corps with trees and livestock & Tanneberger et al. 2021 \\
\hline - Eco-intensification and regenerative agriculture & Ullah et al. 2020; Lal 2020 \\
\hline - Plantations (coffee), and forest agriculture & $\begin{array}{l}\text { Waheed et al. 2018; Birkenberg and } \\
\text { Birner } 2018\end{array}$ \\
\hline - Agroforestry & Briner et al. 2011 \\
\hline
\end{tabular}

from cultivation of rice paddies, raising of livestock, and management of manure. Two among principal sinks of atmospheric $\mathrm{CO}_{2}$ are photosynthesis (net primary production, net ecosystem production, and net biome production) and sequestration of $\mathrm{C}$ in soil as soil organic matter and secondary carbonates (figure 1).

\section{SPARING LAND FOR NATURE BY NEGATIVE EMISSION FARMING}

Agriculture is practiced on almost 5 billion ha (12.4 billion ac) of land. Not only is this land area already excessive and unnecessary, but there are also organizations and communities demanding that more land be brought under agriculture by 2050 through deforestation of tropical rainforests, burning of grasslands/savannas, drainage of peatlands, and flood-based irrigation of deserts into rice paddies. These natural ecosystems, especially rainforests and peatlands along with grasslands, are major reservoirs of $\mathrm{C}$ in soil (SOC and $\mathrm{SIC}$ ) and in vegetation. Therefore, come what may, C stocks of natural ecosystems (along with wildlife and its habitat) must be protected. Furthermore, one-third of the world soils are degraded by erosion, salinization, acidification, pollution/contamination, depletion of SOC and nutrient stocks, etc.(FAO and ITPS 2015). These degraded soils and ecosystems, strongly depleted of their C stocks, must be restored by re-carbonization of both the soils and the vegetation. Protection and restoration, implemented in conjunction with technological options that lead to NEF, will also spare land for nature (figure 2). Humanity should have a goal of returning at least one-third of the land used for agriculture ( 1.5 billion ha $[\sim 4$ billion ac]) to nature by 2050.The United Nations Food System Summit scheduled for the fall of 2021 provides the pertinent event to promote the adoption of this land-sparing concept. The summit provides a unique opportunity for the world population to rise above local, national, and regional politics and give the highest priority to nature and the planet.

\section{TRANSLATING WORDS INTO DEEDS AND SCIENCE INTO ACTION}

Now is the right time to strengthen the Clean Air Act (1967) and Clean Water Act (1972) with the new and long-overdue "Soil Quality Act" in conjunction with the forthcoming farm bill (2023). The proposed act must have the provision to reward farmers for restoration of degraded soils by payments for ecosystem services through sequestration of both SOC and SIC. While payments for geological sequestration of $\mathrm{CO}_{2}$ deep into saline aquifers or stable rock formations are justified at US $\$ 50 \mathrm{t}^{-1}$ (US $\$ 45 \mathrm{tn}^{-1}$ ) of $\mathrm{CO}_{2}$ and should be paid, land managers (farmers, ranchers, and foresters) should also be rewarded for long-term sequestration of atmospheric $\mathrm{CO}_{2}$ into soil and the biomass $\mathrm{C}$ stocks at 


\section{Figure 1}

Important sources and sinks of atmospheric carbon dioxide $\left(\mathrm{CO}_{2}\right)$ in agriculture. Emission negative farming implies increasing sinks and reducing sources so that there is a significant drawdown of atmospheric $\mathrm{CO}_{2}$, much more than just offsetting the emissions from farm operations, and, therefore, increasing photosynthesis of agricultural crops is a major sink along with carbon sequestration in soil. $\mathrm{SOC}=$ soil organic carbon. $\mathrm{SIC}=$ soil inorganic carbon.

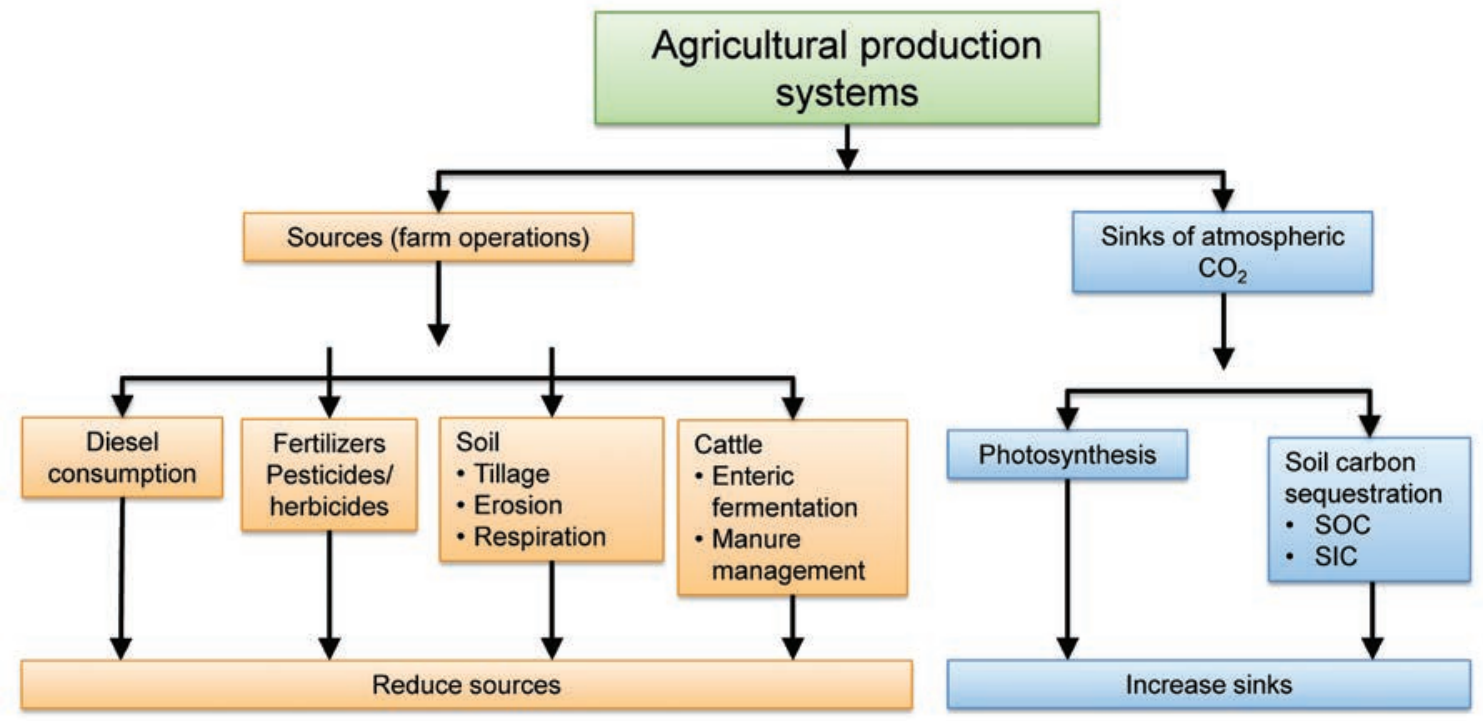

\section{Figure 2}

Negative emission farming involving adoption of science-based management (cropland, grazing lands, horticultural/plantations), along with protection of natural ecosystems and restoration of degraded lands, can lead to sparing land for nature. NPP = net primary productivity. NEP = net ecosystem productivity. NBP = net biome productivity.

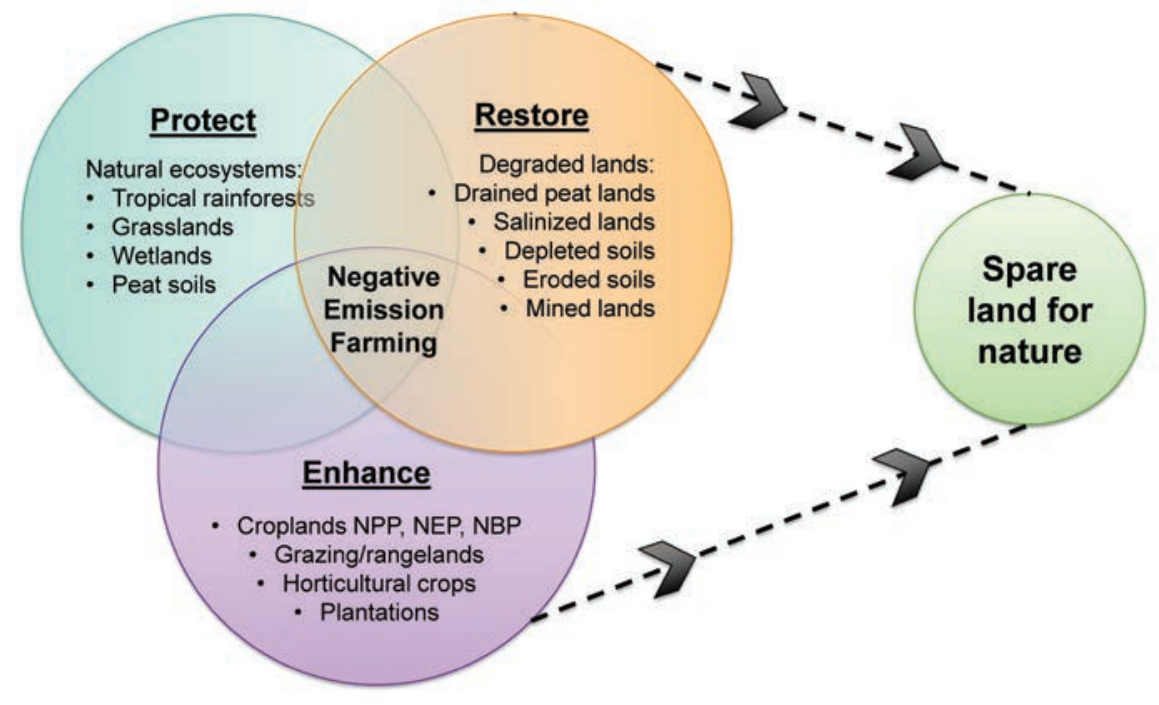

the same rate. Similar to geological sequestration, there is also a need for development of protocols for measurement and verification of the amount of $\mathrm{C}$ sequestered in soils (cropland, grazing lands, and forest lands) and in above- and belowground biomass of forest and woodlands. However, payment per $\mathrm{C}$ credit $\left(1 \mathrm{t}\right.$ [1.1 tn] of $\mathrm{CO}_{2}$ equivalent) must be based on net value with due accounting of $\mathrm{CH}_{4}$ and $\mathrm{N}_{2} \mathrm{O}$ from all sources and sinks. That being the case, there should be no difference in payment between geological and terrestrial sequestration. After all, there is no difference in the global warming whether GHGs are emitted from agriculture or industrial sources. There is no cause for complacency, and now is the time to translate words into deeds and science into action.

\section{REFERENCES}

Abegunde, V.O., M. Sibanda, and A. Obi. 2019. The dynamics of climate change adaptation in sub-Saharan Africa: A review of climate-smart agriculture among small-scale farmers. Climate 7(11):132.

Ahn, C., and N.E.B. Cowern. 2011. Anthropogenic climate change in the zero-carbon era. In Springer Proceedings in Physics, 9-19. New York: Springer Science and Business Media, LLC.

Arnell, N.W., A.L. Kay, A. Freeman, A.C. Rudd, and J.A. Lowe. 2021. Changing climate risk in the UK: A multi-sectoral analysis using policyrelevant indicators. Climate Risk Management 31(January 2021):100265.

Bataille, C., H. Waisman, Y. Briand, J. Svensson, A. VogtSchilb, M. Jaramillo, R. Delgado, R. Arguello, L. Clarke, T. Wild, F. Lallana, G. Bravo, G. Nadal, G. Le Treut, G. Godinez, J. Quiros-Tortos, E. Pereira, M. Howells, D. Buira, J.Tovilla, J. Farbes, J. Ryan, D. De La Torre Ugarte, M. Collado, F. Requejo, X. Gomez, R. Soria, D.Villamar, P. Rochedo, and M. Imperio. 2020. Net-zero deep decarbonization pathways 
in Latin America: Challenges and opportunities. Energy Strategy Reviews 30(July 2020):100510.

Birkenberg, A., and R. Birner. 2018. The world's first carbon neutral coffee: Lessons on certification and innovation from a pioneer case in Costa Rica.Journal of Cleaner Production 189(July 2018):485-501.

Briner, S., M. Hartmann, and B. Lehmann. 2011. Is agroforestry an economic opportunity for carbon-neutral animal production? Agrarforschung Schweiz 2(1):12-19.

Brohm, K.-A., and S. Klein. 2020. The concept of climate smart agricultue - A classification in sustainable theories. International Journal for Quality Research 14(March 1, 2020):291-302.

Chandio,A.A.,W.Akram, F.Ahmad, and M.Ahmad. 2020. Dynamic relationship among agriculture-energy-forestry and carbon dioxide $\left(\mathrm{CO}_{2}\right)$ emissions: Empirical evidence from China. Environmental Science and Pollution Research 27(27):34078-34089.

Chen, R., R. Zhang, and H. Han. 2021. Climate neutral in agricultural production system: A regional case from China. Environmental Science and Pollution Research 2021. DOI:10.1007/ s11356-021-13065-8.

Dorneanu, M. 2017. Intensive farming versus agriculture environmentally sustainable. Quality - Access to Success 18(Supplement 2):195-197.

Dou, X. 2018. Low carbon agriculture and GHG emission reduction in China: An analysis of policy perspective. Theoretical Economics Letters 08(January 1, 2018):538-556.

FAO, and ITPS (Food and Agriculture Organization of the United Nations and Intergovernmental Technical Panel on Soils). 2015. Status of the World's Soil Resources (SWSR) - Main Report. Rome, Italy: Food and Agriculture Organization of the United Nations and Intergovernmental Technical Panel on Soils.

Frankelius, P. 2020. A proposal to rethink agriculture in the climate calculations. Agronomy Journal 112(4):3216-3221.

IPCC (Intergovernmental Panel on Climte Change). 2007.AR4 Climate Change 2007: Synthesis Report. Contributions of Groups I, II, and III to the Fourth Assessment Report of IPCC. Geneva, Switzerland: Intergovernmental Panel on Climte Change.

IPCC. 2018. Global Warming of $1.5^{\circ} \mathrm{C}$ : An IPCC Special Report on the Impacts of Global Warming of $1.5^{\circ} \mathrm{C}$ Above Pre-Industrial Levels and Related Global Greenhouse Gas Emission Pathways, in the Context of Strengthening the Global Response to the Threat of Climate Change, eds.V. Masson-Delmotte, P. Zhai, H.-O. Pörtner, D. Roberts, J. Skea, and P.R. Shukla. Geneva, Switzerland: Intergovernmental Panel on Climte Change.
Jansson, C., S.D. Wullschleger, U.C. Kalluri, and G.A. Tuskan. 2010. Phytosequestration: Carbon biosequestration by plants and the prospects of genetic engineering. BioScience 60(9):685-696.

Lal, R. 2015. A system approach to conservation agriculture. Journal of Soil and Water Conservation 70(4):82A-88A. https://doi. org/10.2489/jswc.70.4.82A.

Lal, R. 2018. Digging deeper: A holistic perspective of factors affecting soil organic carbon sequestration in agroecosystems. Global Change Biology 24(8):3285-3301.

Lal, R. 2020. Regenerative agriculture for food and climate. Journal of Soil and Water Conservation 75(5):123A-124A. https://doi.org/10.2489/ jswc.2020.0620A.

Lal, R., J. Bouma, E. Brevik, L. Dawson, D. J. Field, B. Glaser, R. Hatano, A. Hartemink, T. Kosaki, B. Lascelles, C. Monger, C. Muggler, G. M. Ndzana, S. Norra, X. Pan, R. Paradelo, L. B. ReyesSánchez, T. Sandén, B.R. Singh, H. Spiegel, J. Yanai, and J. Zhang. 2021. Soils and Sustainable Development Goals of the United Nations: An IUSS Perspective. Geoderma Regional. In press.

Nisbet, E.G., R.E. Fisher, D. Lowry, J.L. France, G. Allen, S. Bakkaloglu, T.J. Broderick, M. Cain, M. Coleman, J. Fernandez, G. Forster, P.T. Griffiths, C. P. Iverach, B.FJ. Kelly, M.R. Manning, P.B.R. Nisbet-Jones, J.A. Pyle, A. Townsend-Small, A. al-Shalaan, N. Warwick, and G. Zazzeri. 2020. Methane mitigation: Methods to reduce emissions, on the path to the Paris Agreement. Review of Geophysics 58(1):e2019R G000675.

Pradhan, B.B., R.M. Shrestha, A. Pandey, and B. Limmeechokchai. 2018. Strategies to achieve net zero emissions in Nepal. Carbon Management 9(5):533-548.

Ross, K. 2016. Preparing for an uncertain future with climate smart agriculture. California Agriculture $70(1): 4-5$.

Sà, J.C. de M., R. Lal, C.C. Cerri, K. Lorenz, M. Hungria, and P.C. de Faccio Carvalho. 2017. Low-carbon agriculture in South America to mitigate global climate change and advance food security. Environment International 98(January 2017):102-112.

Smith, P., and J. E. Olesen. 2010. Synergies between the mitigation of, and adaptation to, climate change in agriculture. The Journal of Agricultural Science 148(5):543-552.

Stein, T. 2021. Despite pandemic shutdowns, carbon dioxide and methane surged in 2020. NOAA Research News, April 7, 2021.

Tanneberger, F., S. Abel, J. Couwenberg, T. Dahms, G. Gaudig, A. Günther, J. Kreyling, J. Peters, J. Pongratz, and $\mathrm{H}$. Joosten. 2021. Towards net zero $\mathrm{CO}_{2}$ in
2050: An emission reduction pathway for organic soils in germany. Mires and Peat 27(2021):1-17.

Thanh Hai, L., Q.B.Tran,V.T.Tra, T.P.T. Nguyen, T.N. Le, H. Schnitzer, G. Braunegg, S. Le, C.T. Hoang, X.C. Nguyen, V.H. Nguyen, W. Peng, S.Y. Kim, S.S. Lam, and Q.Van Le. 2020. Integrated farming system producing zero emissions and sustainable livelihood for small-scale cattle farms: Case study in the Mekong Delta, Vietnam. Environmental Pollution 265(October 2020):114853.

Torres, C.M.M.E., M.M. Kohmann, and C.W. Fraisse. 2015. Quantification of greenhouse gas emissions for carbon neutral farming in the Southeastern USA. Agricultural Systems 137(July 2015):64-75.

Ulgiati, S., A. Zucaro, and S. Dumontet. 2008. Integrated systems and zero emission production patterns in agriculture, industry and the energy sector - Why "GREEN" is not enough. In Sustainable Energy Production and Consumption, eds. F. Barbir and S. Ulgiati, 305325. Springer, Dordrecht.

Ullah, S., C. Ai, S. Huang, D. Song, T. Abbas, J. Zhang, W. Zhou, and P. He. 2020. Substituting ecological intensification of agriculture for conventional agricultural practices increased yield and decreased nitrogen losses in North China. Applied Soil Ecology 147(March 2020):103395.

UNFCCC (United Nations Framework Convention on Climate Change). 2015. Adoption of the Paris Agreement, 21st Conference of the Parties, FCCC/CP/2015/L.9/Rev.1., ed. United Nations. Paris: United Nations.

Waheed, R., D. Chang, S. Sarwar, and W. Chen. 2018. Forest, agriculture, renewable energy, and $\mathrm{CO}_{2}$ emission. Journal of Cleaner Production 172(January 2018):4231-4238.

Wang,Y., B. Sharp, S. Poletti, K.-M. Nam, and C.Yue Wang. 2021. Economic and land use impacts of net zero-emission target in New Zealand. International Journal of Urban Sciences. DOI:10 $.1080 / 12265934.2020 .1869582$.

WMO (World Meteorological Organization). 2020. WMO Greenhouse Gas Bulletin \#16: The State of Greenhouse Gases in the Atmosphere Based on Global Observations through 2019. Geneva, Switzerland:World Meteorological Organization.

Xiao, L., R. Zhao, and X. Zhang. 2020. Crop cleaner production improvement potential under conservation agriculture in China: A meta-analysis. Journal of Cleaner Production 269:122262. DOI:10.1016/j.jclepro.2020.122262.

Żukowska, G., M. Myszura, S. Baran, S. Wesołowska, M. Pawłowska, and Ł. Dobrowolski. 2016. Agriculture vs. alleviating the climate change. Problemy Ekorozwoju 11(January 1,2016):67-74. 